Int. J. Electrochem. Sci., 13 (2018) 9017 - 9028

International Journal of

ELECTROCHEMICAL

SCIENCE

www.electrochemsci.org

\title{
Effect of Arsenic Alloying on the Microstructure and Corrosion Properties of Mg-Al Alloy
}

\author{
An Wang, Weitao Jia, Chunlong Cheng, QiChi Le ${ }^{*}$, Fan Yang
}

Key Lab of Electromagnetic Processing of Materials, Ministry of Education, Northeastern University, Shenyang, Liaoning 110819, PR China

*E-mail: qichil@mail.neu.edu.cn

doi: $10.20964 / 2018.09 .75$

Received: 29 March 2018 / Accepted: 12 May 2018 / Published: 5 August 2018

We report that arsenic alloying significantly accelerates the corrosion process of $\mathrm{Mg}$ - $\mathrm{Al}$ alloy. The microstructure of $\mathrm{Mg}-\mathrm{Al}-\mathrm{As}$ alloy consists of $\alpha-\mathrm{Mg}$ grains, $\beta-\mathrm{Mg}_{17} \mathrm{Al}_{12}$ particles, and $\mathrm{Mg}_{3} \mathrm{As}_{2}$ particles. Gravimetric tests revealed that the average corrosion rates of $\mathrm{Mg}$-Al-As and AZ80 magnesium alloys are $75.48 \mathrm{~mm} / \mathrm{y}$ and $7.06 \mathrm{~mm} / \mathrm{y}$. The acceleration of the corrosion process in $\mathrm{Mg}$ Al-As alloy is mainly attributed to the $\mathrm{Mg}_{3} \mathrm{As}_{2}$ phase, which quickly hydrolyzes to form a $\mathrm{Mg}(\mathrm{OH})_{2}$ film.

Keywords: Magnesium corrosion, Electrochemistry, Arsenic

\section{$\underline{\text { FULL TEXT }}$}

(C) 2018 The Authors. Published by ESG (www.electrochemsci.org). This article is an open access article distributed under the terms and conditions of the Creative Commons Attribution license (http://creativecommons.org/licenses/by/4.0/). 